\title{
Conversion of a Tyrosine Kinase Protein Substrate to a High Affinity Ligand by ATP Linkage
}

Kui Shen and Philip A. Cole*

\section{Supplemental Materials}

Synthesis of ATP-Conjugated Peptide. The nitrophenylalaninyl peptide was assembled on Wang resin using automated solid-phase peptide synthesis via the Fmoc strategy. The nitro group was reduced with $\mathrm{SnCl}_{2} \cdot 2 \mathrm{H}_{2} \mathrm{O}$ (30 eq.) in DMF overnight at room temperature with gentle mixing. ${ }^{1}$ The resin was washed with DMF and $\mathrm{CH}_{2} \mathrm{Cl}_{2}$ and then treated with bromoacetic acid (8 eq.) and DIC (8 eq.) in DMF for $3 \mathrm{~h}$ at room temperature with gentle mixing. The resin was washed and dried as above prior to treatment with a solution containing 5\% phenol, 5\% thioanisole, $2.5 \%$ triisopropylsilane, 5\% water and $82.5 \%$ trifluoroacetic acid for $2 \mathrm{~h}$ at room temperature. The mixture was filtered to remove resin beads and the filtrate concentrated and treated with cold ether to precipitate the bromoacetylated peptide. The crude peptide was triturated twice with cold ether, dried under vacuum, and purified by reverse phase HPLC using $0.5 \%$ TFA in a linear gradient of acetonitrile/water. Electrospray mass spectrometry was used to confirm its structural identity $\left([\mathrm{M}+\mathrm{H}]^{+}\right.$, calcd 1260.3, found 1259.0, 1261.0). The purified bromoacetylated peptide in $0.1 \mathrm{M}$ Tris buffer $(\mathrm{pH}$ 7.0) was treated with ATP $\gamma \mathrm{S}$ (adenosine 5'-O-3thiotriphosphate, 1.5 equivalent; Roche Applied Science, IN) overnight at room temperature and then with DTT (dithiothreitol) or TCEP [tris(2-carboxyethyl)phosphine] (10 equivalent relative to bromoacetylated peptide) in $0.1 \mathrm{M}$ Tris buffer, $\mathrm{pH}$ 7.0) for $3 \mathrm{~h}$ at room temperature. The ATPconjugated peptide (with thiol deprotected) was purified by reverse phase HPLC using a linear gradient of acetonitrile/water under neutral $\mathrm{pH}$ and its identity verified by electrospray mass spectrometry ([MH]', calcd 1612.4, found 1612.0).

Protein Semisynthesis. A catalytically defective form (K295M) of Src tyrosine kinase which expresses well in E. coli was used in this study to avoid ambiguity in Csk kinase assays. E. coli BL21 (DE3) strain $^{2}$ transformed with the src-pTYB2 plasmid that harbored the DNA encoding an N-terminal His ${ }_{6}$ tag and the residues 83-524 of Src K295M mutant was grown in shaker flasks at $37{ }^{\circ} \mathrm{C}$ in the $2 \mathrm{X}$ YT media 
(2 L) containing ampicillin $(100 \mu \mathrm{g} / \mathrm{mL})$, followed by induction with IPTG $(0.6 \mathrm{mM})$ at $\mathrm{A}_{600}-0.6$ at 16 ${ }^{\circ} \mathrm{C}$ for $20 \mathrm{~h}$. Cells were lysed in lysis buffer (25 mM Na-Hepes, pH 8.0/150 mM NaCl/1 mM MgSO $4 / 5 \%$ ethylene glycol $/ 5 \%$ glycerol $/ 0.5 \mathrm{mM}$ phenylmethylsulfonyl fluoride) in the absence of added thiols and loaded onto $2 \mathrm{~mL}$ of chitin resin. The column was washed successively with 10 volumes of the equilibration buffer (25 mM Na-Hepes, pH 7.0/250 mM NaCl/1 mM EDTA/0.1\% Triton X-100) and 10 volumes of the ligation buffer (25 mM Na-Hepes, $\mathrm{pH} 8.0 / 250 \mathrm{mM} \mathrm{NaCl} / 1 \mathrm{mM}$ EDTA). The column was incubated with $1 \mathrm{mM}$ ATP-conjugated peptide and $2 \%$ thiophenol in the ligation buffer at room temperature for $24 \mathrm{~h}$ and then eluted with the ligation buffer. The eluent was extensively dialyzed over 6 days against $20 \mathrm{mM}$ Na-Hepes (pH 7.5), $150 \mathrm{mM} \mathrm{NaCl}$, and $1 \mathrm{mM}$ DTT at $4{ }^{\circ} \mathrm{C}$ and concentrated to about $0.5 \mathrm{mg} / \mathrm{mL}$ (about $350 \mu \mathrm{L}$ ) by ultrafiltration. The protein appeared over $70-80 \%$ pure by SDSPAGE and MALDI-TOF mass spectrometry confirmed it had the correct mass $\left([\mathrm{M}+\mathrm{H}]^{+}\right.$calcd $56.2 \mathrm{kDa}$, found $56.2 \mathrm{kDa}$ ). Concentration of the semisynthetic Src-ATP protein was determined through SDSPAGE analysis and comparison with the phosphorylated Src recombinant protein ${ }^{3}$ whose concentration was determined both by Bradford assay and the von Hippel method. ${ }^{4}$

Kinase Assays. Kinase assays were carried out similarly to that described previously, ${ }^{2,5-7}$ with slight modifications. In brief, reactions were performed at $30^{\circ} \mathrm{C}$ and $\mathrm{pH} 7.4$ with $27.5 \mathrm{nM} \mathrm{Csk}, 2 \mathrm{mM} \mathrm{MnCl}_{2}$, $5 \mu \mathrm{M}$ ATP, $0.75 \mu \mathrm{Ci}\left[\gamma_{-}^{32} \mathrm{P}\right]$ ATP, $200 \mu \mathrm{M}$ undecapeptide $\left(\mathrm{K}_{4} \mathrm{E}_{2} \mathrm{IYF}_{3}\right),{ }^{4} 60 \mathrm{mM}$ Tris-HCl, $10 \mathrm{mM}$ DTT, $200 \mu \mathrm{g} / \mathrm{mL}$ BSA and a designated concentration of inhibitory species (plus $0.4 \% \mathrm{v} / \mathrm{v}$ DMSO in the experiments where PP1 were used or compared) in $15 \mu \mathrm{L}$ reaction volume for 4 min. Reactions were initiated with Csk, quenched with $7.5 \mu \mathrm{L}$ of aqueous Na-EDTA (100 mM, pH 8.0), and then mixed with $5.6 \mu \mathrm{L}$ of a gel loading buffer containing $1 \mathrm{M}$ Tris, $\mathrm{pH} 6.8 / 40 \% \mathrm{v} / \mathrm{v}$ glycerol/14\% SDS/0.06\% Coomassie Blue. A $20 \mu \mathrm{L}$ aliquot of this mixture was loaded onto an $18 \%$ SDS-PAGE in $1 \mathrm{M}$ TrisTricine buffer at $130 \mathrm{~V}$ until the dye front reach $2.5 \mathrm{~cm}$ from the bottom of the gel. The portions of the gels above the dye were excised and stained with Coomassie Blue for about $15 \mathrm{~min}$ and destained for 10 
min to visualize the peptide bands. The radioactivity in peptide band slices was quantitated by scintillation counting (Beckman LS6500). Each data point was carried out in duplicate, giving results that agreed within $20 \%$. The turnover of the limiting substrate ATP (at a sub-saturating $5 \mu \mathrm{M}$ concentration) was kept below 10\%. Assuming Michaelis-Menten kinetics is applicable under above conditions, the percent inhibition $\left(1-V_{i} / V_{0}\right)$ (where $V_{i}$ and $V_{0}$ are the initial rates in the presence and absence of the inhibitor, respectively) of a protein kinase-catalyzed reaction at a given concentration [I] of an ATP-competitive inhibitor with an inhibition constant $K_{i}$ is given by Equation 1 (derived from Michaelis-Menten equation): $1-V_{i} / V_{0}=1-\left(K_{m, A T P}+[\mathrm{ATP}]\right) /\left\{K_{m, A T P}\left(1+[\mathrm{I}] / K_{i}\right)+[\mathrm{ATP}]\right\}=K_{m, A T P}$ $[\mathrm{I}] /\left\{K_{m, A T P}[\mathrm{I}]+K_{i}\left(K_{m, A T P}+[\mathrm{ATP}]\right)\right\}$, where $K_{m, A T P}$ and [ATP] are the Michaelis-Menten constant and the initial concentration of ATP, respectively. The $K_{i}$ can therefore be estimated from the percent inhibition $\left(1-V_{i} / V_{0}\right)$ by transformation of Equation 1 into Equation $2: K_{i}=[\mathrm{I}]\left(1+[\mathrm{ATP}] / K_{m, A T P}\right)^{-1}\{(1-$ $\left.\left.V_{i} / V_{0}\right)^{-1}-1\right\}$. With $K_{m, A T P}=10 \mu \mathrm{M}$ for Csk and $[\mathrm{ATP}]=5 \mu \mathrm{M}$, if a competitive inhibitor at $[\mathrm{I}]=0.33$ $\mu \mathrm{M}$ achieves $70 \%$ inhibition as in the case of Csk inhibition by $0.33 \mu \mathrm{M}$ Src-ATP in the presence of $0.25 \mu \mathrm{M}$ PP1 (Figure 2d), the $K_{i}$ of this inhibitor will be $0.33(1+5 / 10)^{-1}\left(0.70^{-1}-1\right) \mu \mathrm{M}=0.094 \mu \mathrm{M}$, which is about 100 -fold lower than the $K_{m}$ of ATP $(10 \mu \mathrm{M})$.

Pull-Down Assays. These experiments employed either E. coli or NIH3T3 mammalian cell extracts, both of which lack detectable Csk by western analysis. $30 \mu \mathrm{L} \mathrm{Zn}^{2+}$-charged metal chelating column ${ }^{2,6}$ was incubated with about $2.75 \mu \mathrm{g}(10 \mu \mathrm{L})$ of semisynthetic Src-ATP protein or recombinant Src-Phe protein (both containing an $\mathrm{N}$-terminal $\mathrm{His}_{6}$ tag) at $4{ }^{\circ} \mathrm{C}$ for $3 \mathrm{~h}$ and subsequently washed with $75 \mathrm{mM}$ imidazole in PBS buffer (pH 7.4), $500 \mathrm{mM} \mathrm{NaCl}$ in PBS buffer (pH 7.4) and then equilibrated with PBS buffer $(\mathrm{pH}$ 7.4) to generate bead-immobilized proteins. These bead-immobilized Src proteins were then incubated with $20 \mu \mathrm{L}$ cell extracts (dialyzed to remove ATP and other small molecules and containing about $20 \mathrm{mg} / \mathrm{mL}$ of cellular proteins, rendering a final protein concentration of about $5 \mathrm{mg} / \mathrm{mL}$ ) of $E$. coli BL21(DE3) strain (cultured and lysed as above-described) or NIH-3T3 [cultured on tissue culture 
dishes at $37{ }^{\circ} \mathrm{C}$ in $5 \% \mathrm{CO}_{2}$ in high glucose Dulbecco's modified Eagle's medium with $10 \%$ fetal calf serum, 100 units $/ \mathrm{ml}$ penicillin and $100 \mathrm{mg} / \mathrm{ml}$ streptomycin, passaged upon reaching confluence, and

A. (i)

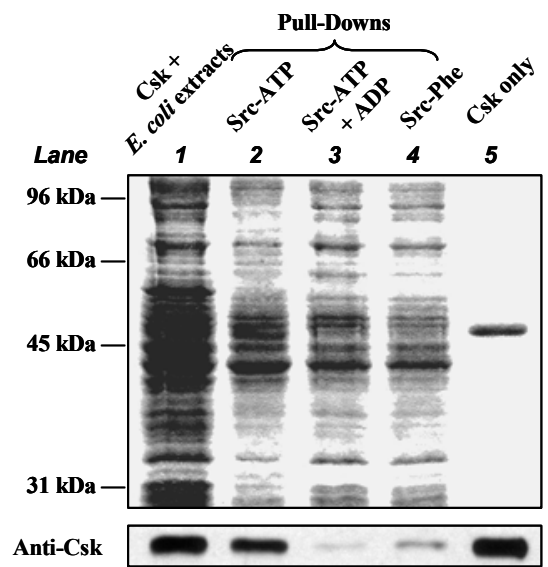

B.

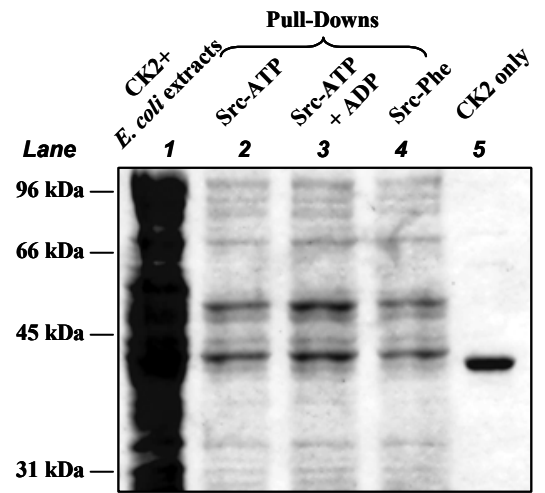

C.

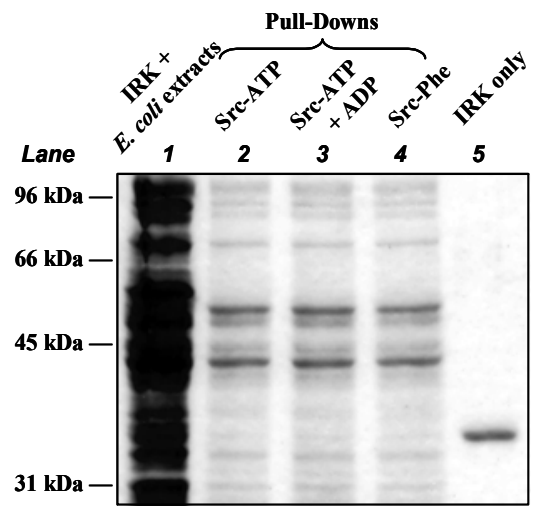

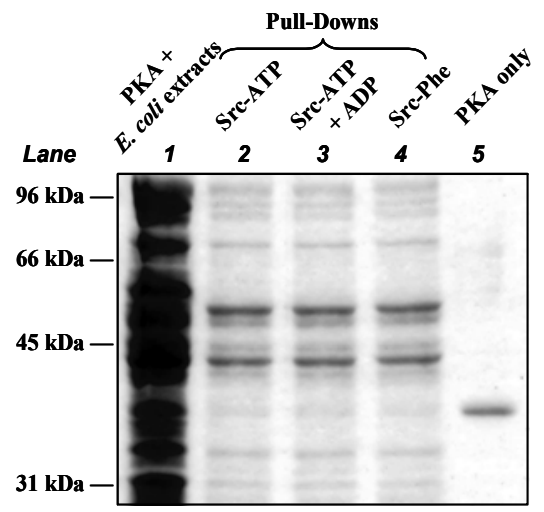

Figure S1. 10\% SDS-PAGE of pull-downs from dialyzed E. coli cell extracts spiked with the target protein (A: Csk; B: CK2; C: IRK; and D: PKA) detected by A(i), B, C and D: Coomassie Blue staining, and A (ii): anti-Csk antibody immunoblotting, respectively [lanes 1 and 5 (each containing about $0.5 \mu$ g of the target protein): target protein + extracts (about 1:100 target protein:cellular proteins), and target protein only; lanes 2-4: Pull-downs by Src-ATP, SrcATP in the presence of $10 \mathrm{mM} \mathrm{ADP}$, and Src-Phe, respectively].

lysed upon reaching 70-80\% confluence for $10 \mathrm{~min}$ on ice in lysis buffer $(0.5 \%$ Nonidet P-40, $20 \mathrm{mM}$ Tris, $\mathrm{pH}$ 8.0, $200 \mathrm{mM} \mathrm{NaCl}, 1 \mathrm{mM}$ EDTA, 0.1\% 2-mercaptoethanol, $2 \mu \mathrm{g} / \mathrm{ml}$ aprotinin, $1 \mu \mathrm{g} / \mathrm{ml}$ leupeptin, $0.7 \mu \mathrm{g} / \mathrm{ml}$ pepstatin, and $25 \mu \mathrm{g} / \mathrm{ml}$ PMSF)] spiked with about $1 \mu \mathrm{M}$ of the target protein [Csk, caesin kinase 2 alpha 1 subunit, isoform a (CK2), insulin receptor kinase (IRK), and protein kinase A (PKA), respectively] in a total final volume of $75 \mu \mathrm{L}$ containing $60 \mathrm{mM}$ Tris- $\mathrm{HCl}, \mathrm{pH} 7.4,50 \mathrm{mM}$ $\mathrm{NaCl}, 8 \mathrm{mM}$ Hepes, $5 \mathrm{mM} \mathrm{MnCl}_{2}$, and $1 \mathrm{mM}$ DTT with or without $10 \mathrm{mM}$ ADP at room temperature for $1 \mathrm{~h}$ and subsequently washed with PBS buffer ( $\mathrm{pH} 7.4$ ), $3 \mathrm{mM}$ peptide $\mathrm{K}_{4} \mathrm{E}_{2} \mathrm{IYF}_{3}$ (a tyrosine kinase 
substrate, used to decrease non-specific binding) in PBS buffer (pH 7.4), $250 \mathrm{mM} \mathrm{NaCl}$ in PBS buffer (pH 7.4), and $75 \mathrm{mM}$ imidazole and $0.5 \%$ Triton $\mathrm{X}-100$ in PBS buffer ( $\mathrm{pH} 7.4$ ). The beads were treated with $1 \mathrm{X}$ SDS gel loading buffer at room temperature for $10 \mathrm{~min}$ and the resultant supernatants loaded onto $10 \%$ SDS-PAGE which were then analyzed by staining with Coomassie Blue and/or by immunoblotting with a rabbit polycolonal anti-Csk antibody (Upstate Biotechnology, NY). For immunoblotting, the nitrocellulose membrane following protein transfer was blocked with $5 \%$ nonfat dry milk in TTBS buffer [TBS buffer (100 mM Tris-HCl, $150 \mathrm{mM} \mathrm{NaCl,} \mathrm{pH} \mathrm{7.5)} \mathrm{with} \mathrm{0.1 \%} \mathrm{Tween} 20$ (ICI America, $\mathrm{OH})]$ overnight at $4{ }^{\circ} \mathrm{C}$ before addition of the primary antibody $\left(1: 10^{3}\right.$ dilution) into the solution, which was then kept at room temperature for 2-4 h. After extensive wash with TTBS buffer, horseradish peroxidase- conjugated donkey anti-rabbit antibody (Amersham Biosciences, NJ) $\left(1: 10^{4}\right.$ dilution with 5\% nonfat dry milk in TTBS buffer) was used to bind the primary antibody and the blot was visualized by an enhanced chemiluminescence assay (ECL, Pierce, IL). As controls, the cell extracts containing about $0.5 \mu \mathrm{g}$ exogenous target protein and the target protein only were also loaded (Figure 3 and Figure S1).

\section{References}

(1) Parang, K.; Till, J. H.; Ablooglu, A. J.; Kohanski, R. A.; Hubbard, S. R.; Cole, P. A. 2001, Nat. Struct. Biol. 8, 37-41.

(2) Wang, D.; Cole, P. A. 2001, J. Am. Chem. Soc. 123, 8883-8886.

(3) Wang, D.; Esselman, W. J.; Cole, P. A. 2002, J. Biol. Chem. 277, 40428-40433.

(4) Gill, S. C.; von Hippel, P. H. 1989, Anal. Biochem. 182, 319-326.

(5) Williams, D. M.; Cole, P. A. 2002, J. Am. Chem. Soc. 124, 5956-5957.

(6) Wang, D.; Huang, X.-Y.; Cole, P. A. 2001, Biochemistry 40, 2004-2010.

(7) Sondhi, D.; Xu, W.; Songyang, Z.; Eck, M. J.; Cole, P. A. 1998, Biochemistry 37, 165-172. 